\title{
Key Points Discussion of the Heating Furnace HAZOP Analysis
}

\author{
Li Qiandeng ${ }^{1,2}$ \\ ${ }^{1}$ SINOPEC Research Institute of Safety Engineering, Qingdao Shandong 266071, China \\ ${ }^{2}$ State Key Laboratory of Safety and Control for Chemicals, Qingdao Shandong 266071, China \\ ditianwl@163.com
}

\begin{abstract}
Keywords Heating furnace; HAZOP analysis
Abstract Heating furnace is the key and core equipment in the petrochemical production plant, therefore using risk assessment method to effectively identify and control the possible risk is very important. In this paper, how to consider the heating furnace danger and operational problems in the HAZOP analysis were introduced. Through using delayed coking furnace HAZOP analysis as an example, combined with the key points that need to be concerned and analyzed in heating furnace HAZOP analysis, the author provided the heating furnace HAZOP analysis results under these key points, and a meaningful reference for the personnel engaged in HAZOP analysis and safety management.
\end{abstract}

\section{Introduction}

For decades, the technical innovation brought enormous changes to the petrochemical industry, new products constantly emerging, unit scale gradually expanding, process systems are becoming more and more complex, operating conditions are becoming more and more severe. Followed by a series of major process safety accidents, which make the whole industry gradually realized that system methods and techniques are in urgent need to prevent process safety accidents.

Due to the advantage of comprehensive, systematic and meticulous, hazard and operability analysis (HAZOP) analysis has been widely applied to the process hazard analysis of petroleum and petrochemical, etc ${ }^{[1][2]}$, and recommended by many international safety standards ${ }^{[3]}$. In addition, HAZOP analysis has also been widely spread and applied by the global petroleum and petrochemical companies, chemical production enterprises, design and construction companies. During the process of HAZOP application abroad, in order to guarantee the analysis quality and guide the enterprise personnel to do the HAZOP analysis better, many large-scale petrochemical enterprises have established the HAZOP analysis methods and main points suitable for their own enterprise. Heating furnace is the high temperature reaction and heating equipment in the process of chemical production. With the development of chemical industry, there are more and more types and kinds of chemical industry heating furnace, many furnaces are key and core equipment among the production facilities. Therefore, how to consider the risk and operability, make the focus points clear, seize the key points of the heating furnace HAZOP analysis, play a key role in identifying and controlling the possible risk, preventing the accidents, protecting the environment, and saving resources.

Based on the heating furnace HAZOP analysis, through using examples, this paper will study and discuss the HAZOP analysis key points of the heating furnace combustion side and process side, and give the HAZOP analysis results and effects. 


\section{Heating furnace HAZOP analysis}

Select a delayed coking unit heating furnace as an example, the heating furnace is double side radiant, the furnace tube is placed in the middle of the chamber, combustors are placed on both sides of the tube rows, flame and hot flue gas is double side radiant to the furnace tube. All the parameters and date of the heating furnace system, including the equipment, pipeline and control system is known, but with no specification due to the space limitation. Choose the piping and instruments diagram (P\&ID diagram) of the heating furnace system, and divide into four nodes as shown in Figure 1.

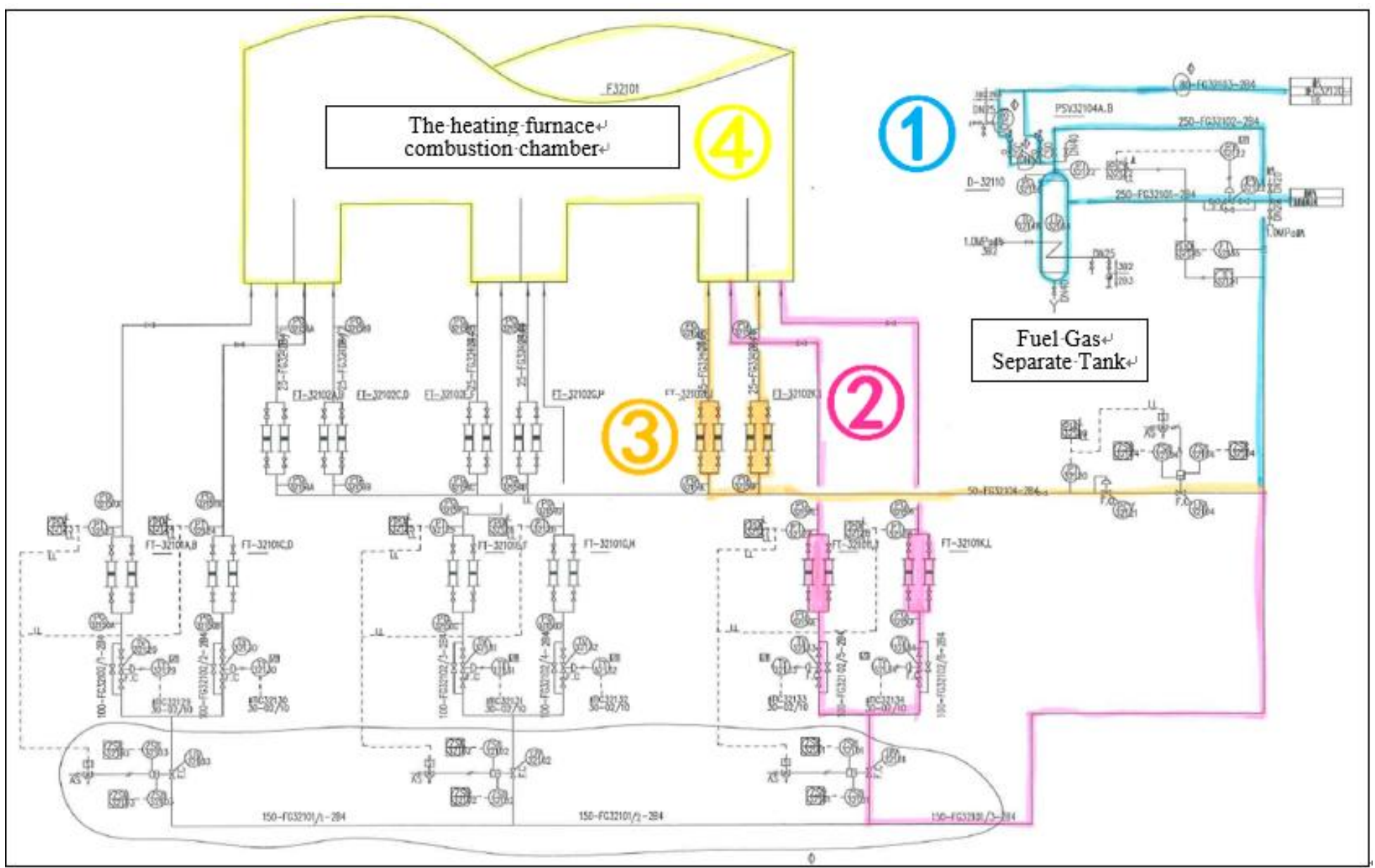

Figure 1 Heating furnace node partition

Using the "parameter precedence" form from the 《Hazard and operability studies (HAZOP studies) - Application guide》 (BS IEC 61882:2001) ${ }^{[4]}$ and 《the Hazard and operability analysis (HAZOP analysis) - Application guide》 (AQ/T3049-2013) ${ }^{[5]}$, and part of the deviations from the "description of the commonly deviations" ${ }^{[1]}$ in the 《the Hazard and operability analysis (HAZOP analysis) - Application guide》 as shown in Table 1. 
Table 1 Description of the chosen deviations

\begin{tabular}{|c|c|}
\hline Deviation & description \\
\hline Flow rate is too low/no flow rate & Flow rate is lower than design/operation requirement/ no flow rate \\
\hline Flow rate is too high & Flow rate is higher than design/operation requirements \\
\hline Reverse flow & Flow toward to the opposite direction of the design or operation target \\
\hline Pressure is too low & Pressure is lower than design/operation requirements \\
\hline Pressure is too high & Pressure is higher than design/operation requirements \\
\hline Temperature is too low & Temperature is lower than design/operation requirements \\
\hline Temperature is too high & Temperature is higher than design/operation requirements \\
\hline Fire/explosion & External fire/explosion effect \\
\hline Concentration is too low & Concentration is lower than design/operation requirements \\
\hline Concentration is too high & Concentration is higher than design/operation requirements \\
\hline Empty tank & Container liquid level loss \\
\hline Liquid level is too low & Liquid level is lower than design/operation requirements \\
\hline Liquid level is too high & Liquid level is higher than design/operation requirements \\
\hline Corrosion & Excessively reduce the operation life period \\
\hline Sampling/test/maintenance & May cause harm, production delay and property loss \\
\hline Production startup & May cause harm, production delay and property loss \\
\hline Production stop & May cause harm, production delay and property loss \\
\hline Human factor & Effect on human from design/operation requirement (such as Continuous working time, \\
& labor intensity and ergonomics ) \\
\hline For & \\
\hline
\end{tabular}

For each analysis node, select the key equipment in the node, make it collocate with the chosen deviations to form detailed deviation, and then according to the detailed deviation to analyze the causes, consequences, existing protection measure, acceptable risk and suggested measures, then complete the heating furnace HAZOP analysis. Combined with the practical application in the HAZOP analysis process, the HAZOP analysis key points of the heating furnace will be discussed next.

\section{The heating furnace combustion chamber side}

\section{Node 1, the fuel gas separate tank}

For the PID figure of the heating furnace combustion chamber side as shown in Figure 1, node 1 is the fuel gas separate tank. Through general deviation, detailed deviation was generated, the reason of the deviation was analyzed, and serious safety consequences that lead by the detailed deviation without consideration of protection were analyzed (the following node analysis was according to the same idea). Part of the HAZOP analysis record form of node 1 was shown as follow. 
Table 2. The HAZOP analysis record form of node 1

\begin{tabular}{|c|c|c|c|c|}
\hline Number & Detailed deviation & Consequence & $\begin{array}{l}\text { Available } \\
\text { protection } \\
\text { measures }\end{array}$ & $\begin{array}{l}\text { Recommended } \\
\text { measures }\end{array}$ \\
\hline 1 & $\begin{array}{l}\text { Liquid level of the } \\
\text { fuel gas separate } \\
\text { tank is too high }\end{array}$ & $\begin{array}{l}\text { May lead to the fuel gas mixed with liquid, the } \\
\text { furnace temperature rise sharply; positive pressure } \\
\text { in the furnace, fire squirt from the fire window; } \\
\text { emit black smoke, burn out of the furnace bottom, } \\
\text { flash fire and explosion. }\end{array}$ & & \\
\hline 2 & $\begin{array}{l}\text { Corrosion of the } \\
\text { fuel gas separate } \\
\text { tank }\end{array}$ & $\begin{array}{l}\text { May lead to leakage of the fuel gas separate tank, } \\
\text { flammable gas cloud will be formed, fire explosion } \\
\text { will happen when meet ignition source. }\end{array}$ & & \\
\hline 3 & $\begin{array}{l}\text { Temperature of the } \\
\text { fuel gas separate } \\
\text { tank is too low }\end{array}$ & $\begin{array}{l}\text { 1、 May cause too much condensate, and easily } \\
\text { lead to the fuel gas mix with liquid. } \\
\text { 2、 May cause water contained in condensate, and } \\
\text { lead to frozen when temperature is low. }\end{array}$ & & \\
\hline 4 & $\begin{array}{l}\text { Drainage operation } \\
\text { of the fuel gas } \\
\text { separate tank }\end{array}$ & $\begin{array}{l}\text { May cause fuel gas straightly drain to the floor } \\
\text { drain, risk of fire and explosion may exist. }\end{array}$ & & \\
\hline
\end{tabular}

Key point 1: can liquids enter into the fuel gas system? If so, whether corresponding measures were being taken ${ }^{[6]}$. Consideration and analysis needed:

(1) whether fuel gas separate tank was set in front of the fuel gas main pipeline of the heating furnace burner, and whether cut-off valve was set in the entrance of the fuel gas separate tank.

(2) whether pilot gas and exhaust gas system could with liquid, if so, whether fuel gas separate tank was set.

(3) whether high liquid level alarm was set, whether steam heating coils were set in the cold region.

(4) whether necessary insulation or heating measures of the pipeline between the fuel gas separate tank were taken according to the local climate condition.

(5) whether the condensate of the fuel gas separate tank was discharged into the closed system; Whether the reverse flow risk of the condensate discharge system and reverse current protection were.

Through the consideration and analysis of the key point 1, the HAZOP analytical records of node 1 is shown in the figure as bellow.

Table 3. The HAZOP analytical records of node 1

\begin{tabular}{|c|c|c|c|c|}
\hline Number & $\begin{array}{l}\text { Detailed } \\
\text { deviation }\end{array}$ & Consequence & $\begin{array}{l}\text { Available protection } \\
\text { measures }\end{array}$ & Recommended measures \\
\hline 1 & $\begin{array}{l}\text { Liquid level } \\
\text { of the fuel } \\
\text { gas separate } \\
\text { tank is too } \\
\text { high }\end{array}$ & $\begin{array}{l}\text { May lead to the fuel gas mixed with } \\
\text { liquid, the furnace temperature rise } \\
\text { sharply; positive pressure in the } \\
\text { furnace, fire squirt from the fire } \\
\text { window; emit black smoke, burn } \\
\text { out of the furnace bottom, flash fire } \\
\text { and explosion. }\end{array}$ & $\begin{array}{l}\text { Be equipped with } \\
\text { on-site } \\
\text { indicator }\end{array}$ & $\begin{array}{lr}\text { Consider adding remote } \\
\text { transmitting liquid level } \\
\text { indicator, and set high liquid } \\
\text { level alarm }\end{array}$ \\
\hline 2 & $\begin{array}{l}\text { Corrosion of } \\
\text { the fuel gas } \\
\text { separate } \\
\text { tank }\end{array}$ & $\begin{array}{l}\text { May lead to leakage of the fuel gas } \\
\text { separate tank, flammable gas cloud } \\
\text { will be formed, fire explosion will } \\
\text { happen when meet ignition source. }\end{array}$ & $\begin{array}{l}\text { Be equipped with } \\
\text { regulating valve and } \\
\text { stop valve before the } \\
\text { entrance of the fuel } \\
\text { gas separate tank }\end{array}$ & $\begin{array}{l}\text { Consider adding shut-off } \\
\text { valve at the entrance of the } \\
\text { fuel gas separate tank on the } \\
\text { main fuel gas pipeline, so that } \\
\text { when fuel gas is leaked, the } \\
\text { main air valve can be shut } \\
\text { down automatically to cut off } \\
\text { the gas supply and prevent the } \\
\text { serious accidents. }\end{array}$ \\
\hline 3 & $\begin{array}{l}\text { Temperature } \\
\text { of the fuel }\end{array}$ & $\begin{array}{l}\text { 3、 May cause too much } \\
\text { condensate, and easily lead to }\end{array}$ & $\begin{array}{l}\text { Fuel gas separate } \\
\text { tank is equipped with }\end{array}$ & $\begin{array}{llr}\text { Consider } & \text { adding } & \text { thermal } \\
\text { insulation } & \text { or heat } & \text { tracing } \\
\end{array}$ \\
\hline
\end{tabular}




\begin{tabular}{|c|l|l|l|l|}
\hline & $\begin{array}{l}\text { gas separate } \\
\text { tank is too } \\
\text { low }\end{array}$ & $\begin{array}{l}\text { the fuel gas mix with liquid. } \\
\text { May cause water contained in } \\
\text { condensate, and lead to frozen } \\
\text { when temperature is low. }\end{array}$ & steam heating coils. & $\begin{array}{l}\text { measures to the pipeline } \\
\text { between }\end{array}$ \\
\hline 4 & $\begin{array}{l}\text { Drainage } \\
\text { operation of } \\
\text { the fuel gas } \\
\text { separate } \\
\text { tank }\end{array}$ & $\begin{array}{l}\text { May cause fuel gas straightly drain } \\
\text { to the floor drain, risk of fire and } \\
\text { explosion may exist. }\end{array}$ & $\begin{array}{l}\text { Consider discharging fuel gas } \\
\text { condensate into the closed } \\
\text { system. }\end{array}$ \\
\hline
\end{tabular}

Node 2, the main burner system

Node 2 is the main burner system, the same as node 1, part of the HAZOP analysis record form of node 2 was shown as follow.

Table 4. The HAZOP analysis record form of node 2

\begin{tabular}{|l|l|l|l|l|}
\hline Number & $\begin{array}{l}\text { Detailed } \\
\text { deviation }\end{array}$ & Consequence & $\begin{array}{l}\text { Available protection } \\
\text { measures }\end{array}$ & $\begin{array}{l}\text { Recommended } \\
\text { measures }\end{array}$ \\
\hline 1 & $\begin{array}{l}\text { Pressure of } \\
\text { the fuel gas } \\
\text { is too low }\end{array}$ & $\begin{array}{l}\text { 1、 } \begin{array}{l}\text { When serious, the deviation may lead to } \\
\text { flameout. If there is fuel gas pressure } \\
\text { fluctuation at this time, the furnace may in } \\
\text { the danger of secondary flash explosion. } \\
\text { 2. }\end{array} \\
\text { May lead to temper. }\end{array}$ & & \\
\hline
\end{tabular}

Key point 2: whether necessary safety measures were set in the fuel gas pipeline ${ }^{[7][8]}$. The following content need to consider and analyze:

(1) When the pipeline pressure before the heating furnace fuel gas regulating valve is equal to or less than $0.4 \mathrm{Mpa}$, and there is no low pressure automatic protection instrument, whether back-fire relief valve are set between each fuel gas regulating valve and heating furnace.

(2) Whether pressure regulating valve and remote controlled stop valve are set in the main fuel gas pipeline. The distance between the stop valve and burner must be longer than $15 \mathrm{~m}$.

(3) Whether cock or ball valve are used as shut-off valve in the fuel gas system.

Through the consideration and analysis of the key point 2, the HAZOP analytical records of node 2 is shown in the figure as bellow.

Table 5. The HAZOP analytical records of node 2

\begin{tabular}{|c|c|c|c|c|}
\hline Number & $\begin{array}{l}\text { Detailed } \\
\text { deviation }\end{array}$ & Consequence & Available protection measures & Recommended measures \\
\hline 1 & \begin{tabular}{ll}
\multicolumn{2}{c}{ Pressure } \\
of the \\
fuel gas \\
is too \\
low
\end{tabular} & $\begin{array}{l}\text { 1. When serious, the } \\
\text { deviation may lead } \\
\text { to flameout. If there } \\
\text { is fuel gas pressure } \\
\text { fluctuation at this } \\
\text { time, the furnace } \\
\text { may in the danger } \\
\text { of secondary flash } \\
\text { explosion. } \\
\text { 2、 May lead to temper. }\end{array}$ & 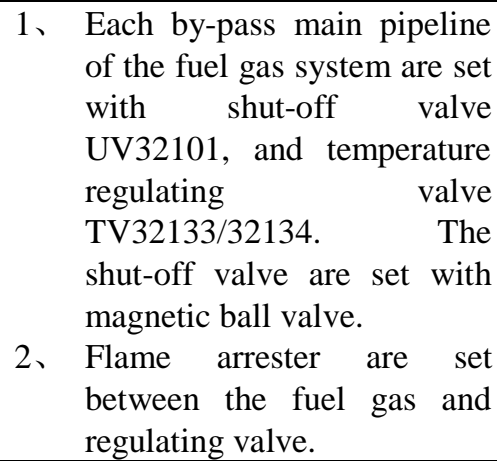 & 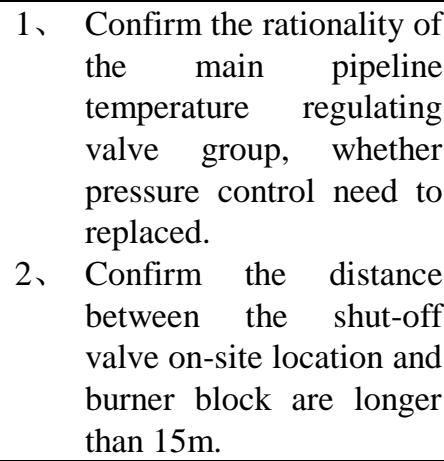 \\
\hline
\end{tabular}

\section{Node 3, the pilot burner system}

Node 3 is the pilot burner system, according to the HAZOP analysis procedure, part of the HAZOP analysis record form of node 3 was shown as follow. 
Table 6. The HAZOP analysis record form of node 3

\begin{tabular}{|c|c|c|c|c|}
\hline Number & Detailed deviation & Consequence & $\begin{array}{l}\text { Available } \\
\text { protection measures }\end{array}$ & $\begin{array}{l}\text { Recommended } \\
\text { measures }\end{array}$ \\
\hline 1 & Main burner is extinct & $\begin{array}{l}\text { The heating furnace is extinct, the fuel } \\
\text { gas may be smoldering in the hearth, } \\
\text { and major risk of secondary explosion } \\
\text { exists in the heating furnace hearth. }\end{array}$ & & \\
\hline 2 & $\begin{array}{l}\text { Pressure of the fuel gas } \\
\text { pipeline in the pilot } \\
\text { burner system is too low }\end{array}$ & $\begin{array}{l}\text { 1. when serious, may lead to flameout, } \\
\text { if the fuel gas pressure fluctuates at } \\
\text { this time, may lead to the risk of } \\
\text { secondary explosion of the hearth. } \\
\text { 2、 may lead to temper. }\end{array}$ & & \\
\hline
\end{tabular}

Key point 3: whether the pilot burner settings can meet the safety requirements ${ }^{[9]}$. The following content need to consider and analyze:

(1) Each burner need to set up pilot burner system.

(2) The fuel gas used by the pilot burner should be delivered from the upstream of the fuel gas regulating valve, and flame arrester need to be set up.

(3) Under any operating conditions, even when the main burner are extinct, air need to be continuously provided into the pilot burner system.

(4) Measures need to be provided to observe the burner and pilot burner flame during ignition and burner operation adjustment.

(5) Whether accident cut-off valve and self-reliance pressure regulating valve are set up in the pilot burner pipeline. Whether local pressure gauge, low pressure alarm and low pressure interlock are set up in the downstream of regulating valve.

Through the consideration and analysis of the key point 3, the HAZOP analytical records of node 3 is shown in the figure as bellow.

Table 7. The HAZOP analytical records of node 3

\begin{tabular}{|c|c|c|c|c|}
\hline Number & $\begin{array}{l}\text { Detailed } \\
\text { deviation }\end{array}$ & Consequence & Available protection measures & Recommended measures \\
\hline 1 & $\begin{array}{l}\text { Main } \\
\text { burner is } \\
\text { extinct }\end{array}$ & $\begin{array}{l}\text { The heating } \\
\text { furnace is extinct, } \\
\text { the fuel gas may } \\
\text { be smoldering in } \\
\text { the hearth, and } \\
\text { major risk of } \\
\text { secondary } \\
\text { explosion exists in } \\
\text { the heating } \\
\text { furnace hearth. }\end{array}$ & $\begin{array}{l}\text { Each burner sets up pilot burner } \\
\text { system. }\end{array}$ & $\begin{array}{l}\text { 1. confirm that when the main burner } \\
\text { stop burning, whether air need to be } \\
\text { provided into the pilot burner } \\
\text { continuously by the blower. } \\
2 \text {. confirm that whether fire windows } \\
\text { are set up in the heating burner, so } \\
\text { that we could observe the burner and } \\
\text { pilot burner flame during ignition and } \\
\text { burner operation adjustment }\end{array}$ \\
\hline 2 & $\begin{array}{l}\text { Pressure } \\
\text { of the } \\
\text { fuel gas } \\
\text { pipeline } \\
\text { in the } \\
\text { pilot } \\
\text { burner } \\
\text { system is } \\
\text { too low }\end{array}$ & $\begin{array}{l}\text { 1. when serious, } \\
\text { may lead to } \\
\text { flameout, if the } \\
\text { fuel gas } \\
\text { pressure } \\
\text { fluctuates at } \\
\text { this time, may } \\
\text { lead to the risk } \\
\text { of secondary } \\
\text { explosion of the } \\
\text { hearth. } \\
\text { 2、 may lead to } \\
\text { temper. }\end{array}$ & $\begin{array}{l}\text { 1. Accident cut-off valve UV } \\
32104 \text { and self-reliance pressure } \\
\text { regulating valve PCV32121 are } \\
\text { set up in the pilot burner pipeline. } \\
\text { Local pressure gauge PG32159, } \\
\text { low pressure alarm PIAL } 32120 \\
\text { and low pressure interlock } \\
\text { PIALL32110 are set up in the } \\
\text { downstream of regulating valve } \\
\text { 2. The fuel gas used by the pilot } \\
\text { burner is delivered from the } \\
\text { upstream of the fuel gas } \\
\text { regulating valve, and flame } \\
\text { arrester is set up. }\end{array}$ & $\begin{array}{l}\text { 1. Set the position of the low pressure } \\
\text { alarm PIAL32120 and low pressure } \\
\text { interlock PIALL } 32110 \text { in the } \\
\text { downstream of regulating valve } \\
\text { after the flame arrester. } \\
\text { 2. In the PID figure, low pressure } \\
\text { interlock cut-off valve UV } 32104 \text { are } \\
\text { set up in the pilot burner, but the } \\
\text { actual interlock logic was cancelled. } \\
\text { We suggest that the pilot burner low } \\
\text { pressure interlock logic need to be } \\
\text { re-confirmed and re-applied. }\end{array}$ \\
\hline
\end{tabular}




\section{Node 4, the heating furnace combustion chamber}

Node 4 is the heating furnace combustion chamber, according to the HAZOP analysis procedure, part of the HAZOP analysis record form of node 4 was shown as follow.

Table 8. The HAZOP analysis record form of node

\begin{tabular}{|c|c|c|c|c|}
\hline Number & Detailed deviation & Consequence & $\begin{array}{l}\text { Available } \\
\text { protection } \\
\text { measures }\end{array}$ & $\begin{array}{l}\text { Recommended } \\
\text { measures }\end{array}$ \\
\hline 1 & $\begin{array}{l}\text { Pressure of the fuel gas } \\
\text { is too low }\end{array}$ & $\begin{array}{l}\text { 1、 when serious, may lead to flameout, if the fuel } \\
\text { gas pressure fluctuates at this time, may lead to } \\
\text { the risk of secondary explosion of the hearth. } \\
\text { 2、 may lead to temper. }\end{array}$ & & \\
\hline 2 & $\begin{array}{l}\text { Pressure of the } \\
\text { combustion chamber is } \\
\text { too high }\end{array}$ & $\begin{array}{l}\text { May lead to poor combustion, and black smoke } \\
\text { produced from the hearth. When serious, may } \\
\text { lead to hearth extinction, and explosion. }\end{array}$ & & \\
\hline 3 & $\begin{array}{l}\text { Oxygen content of the } \\
\text { fuel gas in the } \\
\text { combustion chamber is } \\
\text { too low }\end{array}$ & $\begin{array}{l}\text { When serious, may lead to heating furnace } \\
\text { extinction, flammable gas accumulation into the } \\
\text { heating furnace, and explosion. }\end{array}$ & & \\
\hline 4 & $\begin{array}{l}\text { The heating furnace start } \\
\text { and stop procedure }\end{array}$ & $\begin{array}{l}\text { The operability of the heating furnace start and } \\
\text { stop procedures. }\end{array}$ & & \\
\hline
\end{tabular}

Key point 4: whether enough protection measures are set up to prevent the combustion chamber explosion ${ }^{[10]}$. The following content need to consider and analyze:

(1) Whether all the combustion chambers are set up with the pilot burner system or flame monitoring system.

(2) Whether the pilot burner are set up with safety interlock system when the pilot burner quench.

(3) Whether low pressure of the pilot burner fuel gas or the flame detector could interlock to cut off all the fuel supply.

(4) Whether all the fuel supply could be cut off inside the control room.

(5) Whether the interlock cut-off system are independent of the DCS control and monitoring system, and set up with the cut-off valve.

(6) Whether the interlock cut-off system could be test online, whether measures need to be taken to prevent wrong operation or allow test interruption.

(7) Whether the interlock cut-off system are equipped with alarm to display failure state.

(8) Whether the pilot burner fuel gas is stable and reliable, and could be monitored.

(9) Whether safety and sufficient air or ventilator are provided for the combustion chamber to prevent flameout and out of control of the combustion chamber.

(10) Whether high and low pressure alarms are set up in the downstream of the pipeline control valve of the pilot burner and heating furnace fuel gas.

(11) Whether enough steam purging connectors are set up for the unit start-up.

(12) Whether high pressure alarm is set up for the combustion chamber.

(13)Whether oxygen analyzer are set up in each room of the chimney and multicellular flame heater.

(14) Whether extra alarm and cut-off equipment are set up for the forced air heating furnace to prevent interruption of the combustion air or high pressure in the combustion room(such as the orifice plate ).

Through the consideration and analysis of the key point 4, the HAZOP analytical records of node 4 is shown in the figure as bellow. 
Table 9. The HAZOP analytical records of node 4

\begin{tabular}{|c|c|c|c|c|}
\hline Number & $\begin{array}{l}\text { Detailed } \\
\text { deviation }\end{array}$ & Consequence & $\begin{array}{l}\text { Available protection } \\
\text { measures }\end{array}$ & Recommended measures \\
\hline 1 & $\begin{array}{l}\text { Pressure of } \\
\text { the fuel gas } \\
\text { is too low }\end{array}$ & $\begin{array}{l}\text { 1. when serious, } \\
\text { may lead to } \\
\text { flameout, if } \\
\text { the fuel gas } \\
\text { pressure } \\
\text { fluctuates at } \\
\text { this time, may } \\
\text { lead to the risk } \\
\text { of secondary } \\
\text { explosion of } \\
\text { the hearth. } \\
\text { 2. may lead to } \\
\text { temper. }\end{array}$ & $\begin{array}{l}\text { 1、 Pilot burner is set up in } \\
\text { each combustion } \\
\text { chamber. } \\
2 \text { Low pressure } \\
\text { indicator, and low } \\
\text { pressure interlock to } \\
\text { cut-off the pilot burner } \\
\text { fuel gas supply are set up } \\
\text { after the pilot burner and } \\
\text { main fuel gas pipeline } \\
\text { control valve. } \\
\text { 3、Use blower to ventilate } \\
\text { in the combustion } \\
\text { chamber. }\end{array}$ & $\begin{array}{l}\text { 1. Confirm whether flame detector are set up } \\
\text { in the pilot burner. } \\
\text { 2、 Consider setting up low pressure interlock } \\
\text { to cut off all the fuel gas supply on the pilot } \\
\text { burner main fuel gas pipeline. } \\
\text { 3. Confirm whether manual fuel gas } \\
\text { cutting-off button are set up in the central } \\
\text { control room. } \\
\text { 4、 Whether the interlock cut-off system are } \\
\text { independent of the DCS control and } \\
\text { monitoring system, and set up with the } \\
\text { cut-off valve. } \\
5 \text {. Whether the interlock cut-off system } \\
\text { could be test online, whether measures need } \\
\text { to be taken to prevent wrong operation or } \\
\text { allow test interruption } \\
\text { 6、 Whether the interlock cut-off system are } \\
\text { equipped with alarm to display failure state. }\end{array}$ \\
\hline 2 & $\begin{array}{l}\text { Pressure of } \\
\text { the } \\
\text { combustion } \\
\text { chamber is } \\
\text { too high }\end{array}$ & $\begin{array}{l}\text { May lead to poor } \\
\text { combustion, and } \\
\text { black smoke } \\
\text { produced from } \\
\text { the hearth. When } \\
\text { serious, may lead } \\
\text { to hearth } \\
\text { extinction, and } \\
\text { explosion. }\end{array}$ & $\begin{array}{l}\text { Pressure indicator } \\
\text { PIC32119 are set up in } \\
\text { the combustion chamber }\end{array}$ & $\begin{array}{l}\text { 1. Add high pressure alarm in the } \\
\text { combustion chamber pressure display } \\
\text { PIC } 32119 \\
\text { 2. Confirm whether combustion chamber } \\
\text { high pressure interlock are set up in the } \\
\text { heating furnace to cut off the fuel gas } \\
\text { supply. }\end{array}$ \\
\hline 3 & $\begin{array}{l}\text { Oxygen } \\
\text { content of } \\
\text { the fuel gas } \\
\text { in the } \\
\text { combustion } \\
\text { chamber is } \\
\text { too low }\end{array}$ & $\begin{array}{l}\text { When serious, } \\
\text { may lead to } \\
\text { heating furnace } \\
\text { extinction, } \\
\text { flammable gas } \\
\text { accumulation } \\
\text { into the heating } \\
\text { furnace, and } \\
\text { explosion. }\end{array}$ & $\begin{array}{l}\text { 1. Set up fuel gas oxygen } \\
\text { content monitoring and } \\
\text { controlling system } \\
\text { AIC } 32103 \text { in the heating } \\
\text { furnace, adjust and } \\
\text { control the blower orifice } \\
\text { plate(in another PID } \\
\text { figure). } \\
\text { 2、 Set up stop interlock in } \\
\text { the blower (in another } \\
\text { PID figure) }\end{array}$ & $\begin{array}{l}\text { Confirm whether combustion air interruption } \\
\text { interlock are set up in the heating furnace to } \\
\text { cut off the fuel gas supply. }\end{array}$ \\
\hline 4 & $\begin{array}{l}\text { The } \\
\text { heating } \\
\text { furnace } \\
\text { start and } \\
\text { stop } \\
\text { procedure }\end{array}$ & $\begin{array}{l}\text { The operability } \\
\text { of the heating } \\
\text { furnace start and } \\
\text { stop procedures. }\end{array}$ & & $\begin{array}{l}\text { Confirm whether enough steam purging } \\
\text { connectors are set up for the heating furnace } \\
\text { start-up. }\end{array}$ \\
\hline
\end{tabular}

\section{Conclusion}

Above all, part of the HAZOP analysis key points were enumerated. To complete and improve the heating furnace HAZOP analysis, and improve the safety production level of installations, on the premise of fully understanding normative, and common-sense principles, the HAZOP analysis personnel are required to master scientific analysis concepts, process intention and production requirements, combine previous working experience, design experience, and design specifications, focus on heating furnace HAZOP analysis key points and features, 


\section{References}

[1] Hazard and Operability Analysis (HAZOP) Application Guide [M]. Beijing: China Petrochemical Press, 2012

[2] T. Kletz, HAZOP \& HAZAN, Identtifying and Assessing Process Industry Hazards, fourth edition, 1999

[3] Hazard and Operability Analysis (HAZOP) Fundamentals and Applications [M] .Beijing: China Petrochemical Press, 2012

[4] IEC 61882, Hazard and Operability Studies (HAZOP Studies) Application Guide, 2001

[5] Hazard and Operability Analysis (HAZOP Analysis) Application Guidelines [S]

[6] HAZOP Manual ExxonMobil Chemicals and Refining HAZOP Method [S]

[7] Refining Equipment Process Pipe Flow Design Specification [S]

[8] Petrochemical Design Fire Code [S]

[9] Petrochemical Design Manual [M] Beijing: Chemical Industry Press, 2001

[10]Chemical Technology Design Manual [M]. Beijing: Chemical Industry Press, 2009 